\title{
The Influence of Different Characteristic Demographics of Beef Cattle Farmers on Adoption of Concentrate and UMMB Technology
}

\author{
Sutrisno Hadi Purnomo, ${ }^{*}$ Rendi Fathoni Hadi, Sulistyo \\ Department of Animal Science, Faculty of Agriculture, Sebelas Maret University, Surakarta, Indonesia \\ *Corresponding author's e-mail: sutrisnohadi@staff.uns.ac.id
}

\author{
How to Cite: Purnomo, S.H., Hadi, R.F., Sulistyo. (2018). The Influence of Different \\ Characteristic Demographics of Beef Cattle Farmers on Adoption of Concentrate and UMMB \\ Technology. Int. J. Agr. Syst. 6(2): 111-118
}

\begin{abstract}
This research aimed to find out the influence of different demographic characteristics of beef cattle farmers on adoption of concentrate and UMMB (Urea Mineral Molasses Block) technology. The method employed was a descriptive quantitative with survey technique conducted on beef cattle farmers. The sample was selected using convenience sampling method, with 65 beef cattle farmers as the sample. The primary data was obtained from questionnaire and interview with 65 beef cattle farmers. The secondary data was obtained from Karanganyar Regency's Central Statistic Agency. The data analysis employed included descriptive analysis, validity, reliability, and Oneway ANOVA tests. The results showed that the different demographic characteristics of beef cattle farmers (age, education, main job, job duration, breeding business status and cattle number owned) influence the adoption of concentrate and $U M M B$ technology. The conclusion of research was that the demographic characteristics of beef cattle farmers showed different effects on the adoption of concentrate and UMMB technology.
\end{abstract}

Copyright @2018 IJAS. All rights reserved.

Keywords:

Beef cattle farmers; Characteristics demographics; Concentrate and UMMB technology

\section{Introduction}

The improvement of technology adoption for agricultural transformation and poverty reduction is critical in modern day agriculture (Minten and Barrett, 2008). Technical change in the form of adoption to improve agricultural production technologies has been reported to have positive impacts on agricultural productivity growth in the developing countries (Nin et al, 2003). Promotion of technical change through the generation of agricultural technologies by research and their dissemination to end users plays a critical role in boosting agricultural productivity in developing countries (Mapila, 2011). The availability of modern agricultural production technologies to end users, and the capacities of end users to adopt and utilize these technologies are also critical (Akudungu et al, 2012). 
Several factors may have influence on the extent of adoption of farm practices such as characteristics of farm practice; the adopters; the change agent (extension worker, professional, etc.); and the socio-economic, biological, and physical environment in which the technology take place (Farid et al, 2015). The age, education attainment, income, family size, tenure status, credit use, value system, and beliefs are usually positively related to adoption (Rousan, 2007). Increasing agricultural productivity is critical to meet expected rising demand and, as such, it is instructive to examine recent performance in cases of modern agricultural technologies (Challa, 2013). Agricultural technologies include all kinds of improved techniques and practices which affect the growth of agricultural output (Jain et al., 2009).

In that regard of livestock production also facing low technology adoption, including feed technology adoption. Livestock businesses that are now developing in Indonesian society are poultry farming businesses and ruminant livestock businesses (Simanjuntak, 2004). Livestock business in Indonesia is still not main business. One example is a livestock business located in Ngargoyoso Subdistrict, Karanganyar Regency. The livelihoods of the majority of the population of Ngargoyoso Subdistrict are farming mainly rice, vegetables and tobacco. In general, both agriculture and animal husbandry are still traditionally done so that the results obtained are also relatively low. The low production of livestock is not only caused by the lack of knowledge of farmers but age, education level and livestock status can also affect the level of livestock production.

The beef cattle fattening business is expected to grow and develop into one of the mainstay businesses for farmers and for the local area in an effort to improve the efficiency of beef cattle management. Ngargoyoso Subdistrict has abundant agricultural waste but not too many farmers who utilize agricultural waste into animal feed that uses appropriate technology. This requires feed processing technology with the application and utilization of agricultural waste into concentrate feed and UMMB (Urea Mineral Molasses Block) which can increase the productivity of beef cattle. UMMB is an additional feed supplement for ruminants, in the form of solid which is rich in food substances, made from the main ingredients in the form of molasses as an energy source, urea as a source of protein, complementary food substances, minerals and other filling ingredients.

The application of UMMB processing technology and concentrate for farmers has different revenue results. There are farmers who can accept the existence of a new technology, but there are also farmers who reject the existence of new technology. One factor that influences these differences is the demographic characteristics of farmers. These characteristics include age, occupation, education, length of farming, livestock ownership status and number of livestock (Rousan, 2007). In this regard, the researcher wants to examine the differences in demographic characteristics of beef cattle farmers toward adoption of concentrate feed technology applications and UMMB. These characteristics include age, education, livestock experience, livestock status and the number of livestock owned.

\section{Method}

\subsection{Research Site and Sampling}

This research was carried out in the area in Ngargoyoso District, Karanganyar Regency, Central Java, Indonesia. The study was divided into two stages, namely the 
pre-survey stage and the survey stage. The pre-survey stage is carried out to determine the location of data collection and respondents. The survey phase is carried out for both primary and secondary data collection. Primary data used include: farmer identity, livestock ownership, livestock experience and adoption of the application of fermentation technology and secondary data that will be used in this study are the general condition of the region (geography, agriculture, livestock), the number of livestock populations from the Regency Statistics Center Karanganyar. Determination of respondents in this study was conducted by convenience sampling method with a total sample of 65 beef cattle farmers in Ngargoyoso District, Karanganyar Regency.

\subsection{Data Analysis}

The results of the study were analyzed by descriptive analysis which was used to describe the general condition of research location and the state of livestock resources including the characteristics of farmers and the amount of agricultural land in Ngargoyoso District. Research analysis includes validity analysis to test a measure that shows the level of validity or validity of a questionnaire question instrument (Arikunto, 2010), the opinion of Muhidin and Abdurahman (2011) which states that if the $r$ value is greater $(>)$ than the value of $r$ table, then instrument items declared valid. Darmawan (2013) stated that for reliability testing using Cronbach Alpha technique, if the coefficient obtained $>0.6$, the research instrument was reliable. and Anova oneway analysis to examine differences in data from more than two groups, namely the demographic characteristics of beef cattle farmers against the adoption of concentrate technology and UMMB. The results of the analysis of variance there were significant differences $(\mathrm{P}<0.05)$, then continued with the Post Hoc Test (Arikunto, 2010).

\section{Results and Discussion}

\subsection{Farmers Characteristics}

Characteristics of respondents include gender, age, education, main occupation, livestock experience, status of livestock business and number of livestock owned. More details can be seen in Table 1.

Table 1. Demographics Characteristics of farmers

\begin{tabular}{lcc}
\hline Gender & Amount & Percentage (\%) \\
\hline Man & 55 & 84.6 \\
Woman & 10 & 15.4 \\
\hline Total & 65 & 100 \\
\hline Age (year) & Amount & Percentage (\%) \\
\hline $20-30$ & 18 & 27.7 \\
$31-40$ & 23 & 35.4 \\
$41-50$ & 17 & 26.2 \\
$>50$ & 7 & 10.8 \\
\hline Total & 65 & 100 \\
\hline Education & Amount & Percentage (\%) \\
\hline None & 3 & 4.6 \\
Elementary & 46 & 70.8 \\
J High School & 11 & 16.9 \\
S High School & 5 & 7.7 \\
\hline Total & 65 & 100 \\
\hline
\end{tabular}




\begin{tabular}{lcc}
\hline Main occupation & Amount & Percentage (\%) \\
\hline Farmers & 52 & 80.0 \\
Farm workers & 9 & 13.8 \\
Trader & 4 & 6.2 \\
\hline Total & 65 & 100 \\
\hline Job experience & Amount & Percentage (\%) \\
(Year) & & \\
\hline$<1$ & 3 & 4.6 \\
$1-5$ & 17 & 26.2 \\
$6-10$ & 12 & 18.5 \\
$11-15$ & 9 & 13.8 \\
$>15$ & 24 & 36.9 \\
\hline Total & 65 & 100 \\
\hline Livestock business status & Amount & Percentage (\%) \\
\hline One's own & 45 & 69.2 \\
Family own & 14 & 21.5 \\
Rowdy own & 6 & 9.2 \\
\hline Total & 65 & 100 \\
\hline Population (head) & Amount & Percentage (\%) \\
\hline $1-2$ & 33 & 50.8 \\
$3-4$ & 14 & 21.5 \\
$>5$ & 18 & 27.7 \\
\hline Total & 65 & 100 \\
\hline
\end{tabular}

The demographic characteristics of the farmers studied were age, education, main occupation, livestock experience, the status of the livestock business and the number of livestock owned. The highest gender is male as many as 55 people. The highest age is in the age range of 31-40 years as many as 23 people, the most education is elementary school of 46 people, the main job is as many as 52 people, the experience of breeding > 15 years as many as 24 people, the status of the most livestock business is self-owned as many as 45 people and the largest number of livestock owned by breeders is a range of 1-2 head as many as 33 people. According to Rachmat (2007) the diversity of perceptions includes personal factors that exist in an individual's age, education, knowledge, experience, land tenure and so on. The level of education, age, and suitability of activities with needs is a personal factor that can affect the level of participation.

\subsection{Testing of Research Instruments (Validity Test and Reliability Test)}

A study is expected to minimize measurement errors so that the research approaches the real one. Fulfilling these requirements, the validity and reliability test will be tested in this study. The test results of all research variables $r$ count $>r$ table with $n=65$, obtained $r$ table $=0.241$. Validity test in this study shows that 12 questions from 65 respondents get the results that $r$ count $>r$ table, so that all items in the research question are declared valid or can be used as a data collection tool, such as the opinion of Muhidin and Abdurahman (2007) which states that determining validity data is by comparing $r$ count values and $r$ table values. the criteria if the $r$ count is greater $(>)$ than the $r$ table value, then the instrument item is declared valid. Reliability testing in this study showed reliable results, because the 12 questions from 65 respondents obtained 0.723 results, such as Darmawan's opinion (2013) that for reliability testing 
using Cronbach Alpha technique, if the coefficient obtained> 0.6, then the research instrument was reliable.

Tabel 2. Oneway ANOVA and Post Hoc Test characteristics demographic towards adoption of concentrate technology and UMMB

\begin{tabular}{|c|c|c|c|c|c|c|}
\hline \multirow[b]{2}{*}{ Variabel } & \multicolumn{6}{|c|}{ Technology adoption } \\
\hline & $\mathrm{N}$ & Mean & $\begin{array}{c}\text { Std. } \\
\text { Deviation }\end{array}$ & $\mathrm{F}$ & Sig & $\begin{array}{c}\text { Post Hoc } \\
\text { Test }\end{array}$ \\
\hline \multicolumn{7}{|l|}{ Age $\left(X_{1}\right)$} \\
\hline $1.20-30$ years & 18 & 3.870 & 0.0814 & 3.744 & $0.016^{*}$ & $2<3^{*}$ \\
\hline $2.31-40$ years & 23 & 3.844 & 0.0481 & & & \\
\hline $3.41-50$ years & 17 & 4.117 & 0.0567 & & & \\
\hline 4. $>50$ years & 7 & 3.904 & 0.1051 & & & \\
\hline \multicolumn{7}{|l|}{ Education $\left(X_{2}\right)$} \\
\hline 1.None & 3 & 4.027 & 0.2097 & 3.423 & $0.023^{*}$ & $2<4^{*}$ \\
\hline 2.Elementary & 46 & 3.869 & 0.2841 & & & \\
\hline 3.J High School & 11 & 4.007 & 0.2219 & & & \\
\hline 4.S High School & 5 & 4.250 & 0.3118 & & & \\
\hline \multicolumn{7}{|l|}{ Main Occupation } \\
\hline$\left(X_{3}\right)$ & 52 & 3.881 & 0.2563 & 7.210 & $0.002^{* *}$ & $1<2^{*}$ \\
\hline 1.Farmers & 9 & 4.240 & 0.3130 & & & \\
\hline 2.Farm workers & 4 & 3.854 & 0.2753 & & & \\
\hline \multicolumn{7}{|l|}{ 3.Trader } \\
\hline \multicolumn{7}{|c|}{ Job experience $\left(X_{4}\right)$} \\
\hline $1 .<1$ years & 3 & 4.027 & 0.1924 & 3.386 & $0.015^{*}$ & $3<5^{*}$ \\
\hline $2.1-5$ years & 17 & 3.892 & 0.3343 & & & \\
\hline $3.6-10$ years & 12 & 3.736 & 0.2725 & & & \\
\hline $4.11-15$ years & 9 & 3.861 & 0.2635 & & & \\
\hline 5. $>15$ years & 24 & 4.066 & 0.2238 & & & \\
\hline \multicolumn{7}{|c|}{$\begin{array}{l}\text { Livestock business } \\
\text { status }\left(X_{5}\right)\end{array}$} \\
\hline 1.One's own & 45 & 3.961 & 0.2976 & 3.237 & $0.046^{*}$ & $1>3^{*}$ \\
\hline 2.Family own & 14 & 3.946 & 0.2082 & & & \\
\hline 3.Rowdy own & 6 & 3.652 & 0.2898 & & & \\
\hline \multicolumn{7}{|l|}{ Population $\left(X_{6}\right)$} \\
\hline 1.1-2 head & 33 & 3.833 & 0.3019 & 4.478 & $0.015^{*}$ & $1<2^{*}$ \\
\hline 2.3-4 head & 14 & 4.077 & 0.2499 & & & \\
\hline 3. $>5$ head & 18 & 3.990 & 0.2898 & & & \\
\hline
\end{tabular}

${ }^{*} \mathrm{P} \leq 0.05$ and ${ }^{* *} \mathrm{P} \leq 0.01$ significant result

Post Hoc Scheffe's Multiple P $\leq 0.05$

\subsection{Adoption of Concentrate and UMMB Technology}

The results of the study showed that the age of the farmers (X1) showed significant results on the adoption of Concentrated technology and UMMB with the results of 0.016 (Table 2). After further testing with Post Hoc Test, there were two different age categories, namely 31-40 years and $41-50$ years. It can be concluded that X1 has a different effect on the adoption of Concentrate and UMMB technology. As Soekoharto's statement (1999) states that the age range of 30 to 50 years is still classified as productive, the significant age in (Table 2) can be said to be classified as productive. Older farmers certainly no longer have the passion to develop their farming business. According to Slamet (1994), states that age factors are very influential in participation. 
There were differences in educational factors (X2) toward the adoption of Concentrate technology and UMMB which had a significant effect $(\mathrm{P}<0.05)$ with the results of 0.023 (Table 2). After the data was tested further using Post Hoc Test, it was found that farmers with elementary and high school education had significant results, so it could be said that X2 had a different effect on the adoption of Concentrate and UMMB technology. This is because most respondents have elementary school education and low education levels are caused by economic conditions that are still not well established because the work of most respondents is farmers and farm laborers. Mosher (1987) states that education is a factor that accelerates livestock development, the lower the level of education, the harder it is for farmers to absorb technology, namely Concentrate and UMMB technology. The higher education is also the easier it is to accept technology as said by Soekartawi (1988), that education is one very important indication in determining the success of a business because by obtaining education it will be able to adopt science and technology well. The existence of this ability is expected to be able to apply everything that has been obtained in his efforts better. Slamet (1994), states that the level of education of respondents who are grouped into three groups with low education, namely elementary school down, the group educated above elementary school until high school graduates and highly educated, those who are educated above high school.

There are differences in the main occupational factors (X3) in (Table 2) showing very significant results $(\mathrm{P}<0.01)$ with a value of 0.002 . The Post Hoc Test shows that farmers and farm laborers have a significant influence on the adoption of Concentrate technology and UMMB, because the main jobs are mostly farmers and farm laborers, this means that factor X3 has a different effect on the adoption of Concentrate and UMMB technology.

There are differences in the experience of farming factors (X4) in (Table 2) obtaining significant results $(\mathrm{P}<0.05)$ which is 0.015 . Post Hoc Test follow-up shows that farmers who experience 6 to 10 years and $>15$ years have significant results. This means that factor X4 has a different effect on the adoption of Concentrate and UMMB technology.

There are differences in livestock business status factors (X5) in (Table 2), obtaining significant results $(\mathrm{P}<0.05)$ with the results of 0.046 . After further testing with the Post Hoc Test the results obtained that own ownership and rowdy ownership have significant results. This means that factor X5 has a different effect on the adoption of Concentrate and UMMB technology.

There are differences in the factors of the number of livestock or livestock ownership (X6) in (Table 2), giving significant results $(\mathrm{P}<0.05)$ with a value of 0.015 . Post Hoc Test further test gives results that 1-2 head of cattle and 3-4 heads have significant results (Table 2). This means that factor $\mathrm{X} 6$ has a different effect on the adoption of Concentrate and UMMB technology. The number of livestock ownership in beef cattle farmers in Ngargoyoso shows that they are still in a low amount because in addition to the side business, some farmers maintain with a collision system. Livestock ownership is closely related to the adoption of Concentrate and UMMB technology. Farmers who have a lot of livestock are more likely to make improvements to breeding techniques so that the impact on the business results obtained (Jamharir, 1992 cit Ma'ruf, 2000). 


\section{Conclusion}

It can be concluded that differences in demographic characteristics of beef cattle farmers (age, education, main occupation, job experience, livestock business status and number of livestock) have different effects on the adoption of concentrate and UMMB (Urea Mineral Molasses Block) technology.

\section{Acknowledgements}

Sincerest gratitude is expressed to the Research Center and Community Services (LPPM) Universitas Sebelas Maret for the competitive research grant 2018.

\section{References}

Akudugu, MA, E. Guo, S.K. Dadzie. (2012). Adoption of Modern Agricultural Production Technologies by Farm Households in Ghana: What Factors Influence their Decisions? Journal of Biology, Agriculture and Healthcare. 2(3): 1-13

Arikunto, S. (2010). Prosedur Penelitian Suatu Pendekatan Praktek. Edisi Revisi 2010. PT. Rineka Cipta, Jakarta.

Challa, Merga (2013). Determining Factors and Impacts of Modern Agricultural Technology Adoption in West Wollega, Munich, GRIN Publishing GmbH, http:/ / www.grin.com/en/e-book/280336/ determiningfactors-and-impacts-ofmodern-agricultural-technology-adoption.

Darmawan, D. (2013). Metode Penelitian Kuantitatif. PT. Remaja Rosdakarya, Bandung.

Farid K.S., N. Z. Tanny and P. K. Sarma. (2015). Factors affecting adoption of improved farm practices by the farmers of Northern Bangladesh. J. Bangladesh Agril. Univ. 13(2): 291-298.

Jain R. Arora A \& Raju S. (2009). A Novel Adoption Index of Selected Agricultural Technologies: Linkages with Infrastructure and Productivity: Agricultural Economics Research Review. 22(1): 109-120

Mapila, M. A. T. J. (2011). Rural livelihoods and agricultural policy changes in Malawi. Agricultural Innovations for Sustainable Development. In: Manners, G.and Sweetmore, A., (Editors). Accra-Ghana, CTA and FARA, 3: 190-195.

Ma'ruf, M. (2000). Peranan Koperasi Peternakan Sarono Makmur dalam Pengembangan Usaha Sapi Perah Rakyat di Wilayah Kabupaten Sleman. Skripsi Sarjana Peternakan Fakultas Peternakan Universitas Gadjah Mada, Yogyakarta.

Minten, B., \& Barrett, C. B. (2008). Agricultural technology, productivity, and poverty in Madagascar. World Development, 36(5), 797-822.

Mosher A.T. (1987). Menggerakkan dan Membangun Pertanian. Yasaguna. Jakarta.

Muhidin, S. A dan Abdurahman, M. (2007). Analisis Korelasi, Regresi, dan Jalur dalam Penelitian. CV. Pustaka Setia, Bandung.

Nin, A., Arndt, C., \& Precktel, P. (2003). Is agricultural productivity in developing countries really shrinking? New evidence using a modified non parametric approach. Journal of Development Economics .71: 395-415. 
Rakhmat, J. (2007). Persepsi Dalam Proses Belajar Mengajar. Jakarta: Rajawali Pers.

Rousan, L.M. (2007). Factors Influencing Adoption of Improved Farm Practices among Women Farmers in Northern Jordan. American-Eurasian J. Agri. \& Env. Sci., 2 (3), 220-226.

Simanjuntak, S. B. (2004). Bahan Mata Kuliah Pengantar Ilmu Pertanian. Fakultas Pertanian. Universitas Sumatera Utara, Medan.

Slamet, Y. (1994). Pembangunan Masyarakat Berwawasan Partisipasi. Universitas Sebelas Maret Press, Surakarta.

Soekartawi, (1988). Prinsip Dasar Komunikasi Pertanian. Cetakan Pertama. Jakarta: Universitas Indonesia Press

Soekoharto. (1999). Dasar-Dasar Ilmu Penyuluhan. Fakultas Peternakan Universitas Gadjah Mada, Yogyakarta. 